\title{
Risk Factors for Obesity in Adolescents Living in Rural Areas of Buryatia: A Case-Control Study
}

\author{
Lyubov Rychkova, PhD, ScD; Anna Pogodina, PhD, ScD*; Zhanna Ayurova; Olga Berdina, PhD \\ Scientific Centre for Family Health and Human Reproduction Problems \\ Irkutsk, the Russian Federation
}

\begin{abstract}
The aim of the present study was to evaluate the association between early life factors, sociodemographic influences, behavioral characteristics and obesity in adolescents living in rural areas of Buryatia (Russia).

Methods: A case-control study was performed. A total of 158 adolescents aged between 11 and 17 years of age (79 adolescents with normal weight and 79 adolescents with obesity) were included in the study. All the adolescents had their weight and linear growth measured, and BMI was calculated. Height and weight parameters were based on the reference values accepted by the WHO. Obesity was diagnosed at BMI $\geq 95$ th percentile The data on the variables of interest were obtained from questionnaires filled in by parents and adolescents and their medical records from local outpatient clinics.

Results: The results showed that the adjusted ORs and 95\% CIs for obesity were 1.15 (1.05-1.26), 4.87 (1.82-13.02), 3.08 (1.19-7.99) for maternal BMI, growth in infancy and unhealthy eating patterns, respectively. Breastfeeding longer than 12 months showed to play a protective role for the development of obesity in adolescence as compared to a shorter period of breastfeeding $(\mathrm{OR}=0.05,95 \%$ CI: $0.006-0.40)$.

Conclusion: Maternal BMI, rapid growth in infancy and unhealthy eating patterns are associated with increased risk of obesity in adolescents in rural areas of Buryatia, while long-term breastfeeding is a protective factor against obesity. (International Journal of Biomedicine. 2019;9(2):190-195.)
\end{abstract}

Key Words: adolescents $\bullet$ breastfeeding $\bullet$ growth in infancy $\bullet$ obesity $\bullet$ parental body mass index

\section{Introduction}

Obesity is a multifactorial disease that develops from complicated interactions among genetic, environmental, socioeconomic and behavioral factors that lead to an imbalance between energy intake and consumption. ${ }^{(1)}$ Childhood obesity tracks into adulthood, contributing to the early development of type 2 diabetes, cardiovascular diseases, musculoskeletal diseases, obstructive sleep apnea, and some types of cancer. ${ }^{(2)}$

Such a situation provokes concern about the high rate of obesity, not only in adults but also in children and adolescents. According to the research data, about $20 \%$ of children and adolescents in Russia are overweight and 5.7\% suffer from obesity. ${ }^{(3,4)}$ Thus, it is necessary to search for effective strategies to prevent obesity and associated complications that

*Corresponding author: Anna Pogodina, PhD, ScD. Scientific Centre for Family Health and Human Reproduction Problems, Irkutsk, the Russian Federation.E-mail:pogodina_av@inbox.ru influence the modifiable risk factors. It should be noted that the role and character of the risk factors can vary not only among different countries ${ }^{(5)}$ but also among urban and rural areas within the same country. ${ }^{(6)}$ Until now, there have been no studies on the risk factors for obesity among adolescents in rural Russian communities.

It has been proved that the period from conception to 2 years of age is very important for the induction of those pathophysiological disorders that lead to the development of obesity in older age. ${ }^{(7)}$ Any reasonable early childhood intervention will reduce the risk of this imprinting disorder, even when it comes to behavioral and environmental factors that have an impact in later life. Not much success has been achieved in the treatment of obesity, which makes the preventive approach especially relevant.

The aim of the present study was to evaluate the association between early life factors, sociodemographic influences, behavioral characteristics and obesity in adolescents living in rural areas of Buryatia. 


\section{Methods}

The present study was a part of another study focused on the investigation of obesity in adolescent indigenous inhabitants of the Republic of Buryatia. Buryatia is a multinational republic located in the southern part of Eastern Siberia. Its population is 971.8 thousand people of more than a hundred of nationalities, the majority of which are Russians and Buryats. The Buryats belong to the Central Asia type of northern-Asian major mongoloid race. ${ }^{(8)}$

This study was conducted between January 2015 and April 2016. The sampling frame included 1,456 students that had annual screening examinations and were inhabitants of 6 rural municipal regions. The adolescents and their legally authorized representatives were provided the detailed information about the study in written and verbal form. The informed consent form was signed by the legal representatives of 269 adolescents that met the criteria for entry into the study: 11-17 years of age; at least two generations of parents of the same ethnicity; continuous residence of an adolescent in the territory of the specified settlement since birth.

Obesity was diagnosed in 81 adolescents included in the main study; 2 adolescents were later withdrawn from the study due to the coexisting retardation of growth (weight-forheight $\mathrm{z}$-score $<-2$ ). A control group included 79 adolescents compatible by sex, age, ethnicity, and area of living, with normal height and body weight (BMI Z-score $>5$ th and $<85$ th percentile for the distribution for the specified age, height and sex).

Parents of the adolescents from both groups filled in the questionnaires that contained questions on sociodemographic characteristics of their families (age and professional occupation of the parents during pregnancy and presently, parents' education and income level, number of family members living together, number of children in the family), and smoking status of parents.

The information on early development (weight and height at birth, weight gain during the first year of life, feeding patterns and time of solids introduction, and type of solid foods) was obtained from the adolescents' medical records from the outpatient clinics. Duration of breastfeeding was taken as the time during which the subject received any breast milk. The period of exclusive breastfeeding was taken as the period when children were fed only breast milk.

The information on maternal health status during pregnancy, peculiarities of pregnancy development, and child delivery was obtained from the medical records provided by maternity hospitals to outpatient clinics, where these women were managed.

The information on the peculiarities in eating behavior, physical activity, time spent looking at a screen (TV, PC, tablet computer) was obtained from the questionnaires. Routine physical activity of the adolescents was ranged by four levels: 1) adolescents that attended PE (physical education) classes, but had low physical activity outside school and did not attend extracurricular sport activities; 2) adolescents that attended $\mathrm{PE}$ classes and were physically active outside school (routine household chores like looking after the livestock, working in the vegetable garden, and splitting firewood); 3) adolescents that attended PE classes and extracurricular sports activities, but did not have sufficient physical activity outside school; 4) adolescents that attended PE classes and extracurricular sports activities, and were physically active outside school.

The questions on eating habits included the number of meals per day (wholesome meals at a dinner table, excluding snacks), time of the last meal in the evening, meals or snacks at night. The data on the regularity of breakfast meals was not presented because of lack of answers. The data on the height and weight of all the parents was obtained from the medical records of annual screening examinations. Excessive weight in parents was diagnosed at BMI from $25.0 \mathrm{~kg} / \mathrm{m}^{2}$ to $29.9 \mathrm{~kg}$ / $\mathrm{m}^{2}$, obesity $-\geq 30 \mathrm{~kg} / \mathrm{m}^{2}$.

All the adolescents had their weight and linear growth measured, and BMI was calculated. Height and weight parameters were based on the reference values accepted by the WHO, with an AnthroPlus calculator. Obesity was diagnosed at $\mathrm{BMI} \geq 95$ th percentile. $^{(1)}$

The study was conducted in accordance with ethical principles of the Declaration of Helsinki and approved by the Scientific Centre for Family Health and Human Reproduction Problems Ethics Committee. Written informed consent was obtained from all participants.

Statistical analysis was performed using statistical software package SPSS version 21.0 (SPSS Inc, Chicago, IL) For descriptive analysis, results are presented as mean \pm standard deviation (SD), median, interquartile range (IQR; 25th to 75 th percentiles). The Mann-Whitney $U$ test was used to compare continuous variables. Group comparisons with respect to categorical variables are performed using chi-square tests with Yates correction or, alternatively, Fisher's exact test when expected cell counts were less than 5. Binary logistic regression analyses were used to assess the early life, behavioral, and sociodemographic factors associated with adolescent obesity. First, univariate analyses were performed. Second, multivariate analyses (direct LR) were performed that included all variables that were significantly $(P<0.05)$ or borderline significantly $(P<0.1)$ associated with obesity in the univariate analyses. Odds ratios (ORs) and their 95\% confidence intervals (CIs) were calculated by using logistic regression. A probability value of $P<0.05$ was considered statistically significant.

\section{Results}

Clinical, sociodemographic, and behavioral characteristics of the adolescents at the time of their examination are presented in Table 1. Sociodemographic characteristics of the families at the time of assessment were similar in both groups. There was no significant difference in the physical activity and screen time.

However, unhealthy eating habits were observed significantly more often in the group of adolescents with obesity. Mothers of obese adolescents had a higher median BMI and suffered from obesity more often as compared to the control group. BMI of fathers was similar in both groups. Fathers of the adolescents with normal body weight were more often current smokers, which formed a significant intergroup difference in the rate of passive smoking in the family. The early life factors for the adolescents are presented in Table 2. 
Table 1.

Comparison of sociodemographic, parental and life-style characteristics between adolescents with normal weight and obesity

\begin{tabular}{|c|c|c|c|c|c|}
\hline Variable & $\begin{array}{l}\text { Normal } \\
\text { Weight }\end{array}$ & $\mathrm{n}$ & Obesity & $\mathrm{n}$ & $P$-value \\
\hline Age, years & $13(12 ; 15)$ & 79 & $13(12 ; 15)$ & 79 & 1.00 \\
\hline Gender, male & $51(64.6)$ & 79 & $51(64.6)$ & 79 & 1.00 \\
\hline $\begin{array}{l}\text { Ethnicity: } \\
\text { Asians } \\
\text { Russians }\end{array}$ & $\begin{array}{l}51(64.6) \\
28(35.4)\end{array}$ & 79 & $\begin{array}{l}51(64.6) \\
28(35.4)\end{array}$ & 79 & 1.00 \\
\hline Height, $\mathrm{cm}$ & $160.3 \pm 10.1$ & 79 & $162.8 \pm 11.6$ & 79 & 0.158 \\
\hline Weight, kg & $49(43 ; 55)$ & 79 & $75(68 ; 92)$ & 79 & $<0.0001$ \\
\hline BMI & $\begin{array}{c}19.3 \\
(18.1 ; 20.2) \\
\end{array}$ & 79 & $\begin{array}{c}28.6 \\
(27 ; 31) \\
\end{array}$ & 79 & $<0.0001$ \\
\hline BMI z-score & $\begin{array}{c}0.08 \\
(-0.5 ; 0.51) \\
\end{array}$ & 79 & \begin{tabular}{|c|}
2.4 \\
$(2.15 ; 2.7)$ \\
\end{tabular} & 79 & $<0.0001$ \\
\hline $\begin{array}{l}\text { Maternal education level: } \\
\text { high } \\
\text { middle } \\
\text { low }\end{array}$ & $\begin{array}{c}26(32.9) \\
53(67.1) \\
0\end{array}$ & 79 & $\begin{array}{c}23(29.1) \\
54(68.3) \\
2(2.5)\end{array}$ & 79 & 0.334 \\
\hline $\begin{array}{l}\text { Maternal employment: } \\
\text { housewife } \\
\text { work in public service } \\
\text { manual worker } \\
\text { self-employed entrepreneur }\end{array}$ & $\begin{array}{l}21(26.9) \\
33(42.3) \\
23(29.5) \\
1(1.3) \\
\end{array}$ & 78 & $\begin{aligned} & 26(32.9) \\
& 23(29.1) \\
& 27(34.2) \\
& 3(3.8) \\
&\end{aligned}$ & 79 & 0.304 \\
\hline $\begin{array}{l}\text { Paternal education level: } \\
\text { high } \\
\text { middle } \\
\text { low }\end{array}$ & $\begin{array}{c}25(37.9) \\
40(60.6) \\
1(1.5)\end{array}$ & 66 & $\begin{array}{c}15(24.6) \\
44(72.1) \\
2(3.3)\end{array}$ & 61 & 0.243 \\
\hline $\begin{array}{l}\text { Paternal employment: } \\
\text { unemployed } \\
\text { work in public service } \\
\text { manual worker } \\
\text { self-employed entrepreneur }\end{array}$ & $\begin{aligned} & 14(21.5) \\
& 21(32.3) \\
& 25(38.5) \\
& 5(7.7) \\
&\end{aligned}$ & 65 & $\begin{array}{c}13(21) \\
14(22.6) \\
30(48.4) \\
5(8.1) \\
\end{array}$ & 62 & 0.610 \\
\hline Single motherhood & $13(16.5)$ & 79 & $17(21.5)$ & 79 & 0.417 \\
\hline $\begin{array}{l}\text { Number of family } \\
\text { members } \\
\text { living together }\end{array}$ & $4(4 ; 5)$ & 79 & $4(3 ; 5)$ & 78 & 0.261 \\
\hline $\begin{array}{l}\text { Number of children in } \\
\text { the family }\end{array}$ & $2(2 ; 2)$ & 79 & $2(2 ; 2)$ & 78 & 0.360 \\
\hline $\begin{array}{l}\text { Family income: } \\
\text { low } \\
\text { average } \\
\text { above average }\end{array}$ & $\begin{array}{c}7(8.9) \\
65(82.3) \\
7(8.9)\end{array}$ & 79 & $\begin{array}{l}14(17.9) \\
53(67.9) \\
11(14.1)\end{array}$ & 78 & 0.109 \\
\hline Maternal smoking & $15(19)$ & 79 & $23(29.1)$ & 79 & 0.136 \\
\hline Paternal smoking & $57(72.1)$ & 79 & $39(49.4)$ & 79 & 0.003 \\
\hline Smoking of any & $64(81)$ & 79 & $50(63.3)$ & 79 & 0.013 \\
\hline Maternal BMI & $\begin{array}{c}23.8 \\
(20.2 ; 28.7) \\
\end{array}$ & 79 & $\begin{array}{c}28.3 \\
(25.5 ; 30.5) \\
\end{array}$ & 79 & $<.0001$ \\
\hline Paternal BMI & $\begin{array}{c}26.3 \\
(24.4 ; 28.7) \\
\end{array}$ & 66 & $\begin{array}{c}26.7 \\
(23.3 ; 29.4) \\
\end{array}$ & & 0.893 \\
\hline Mother is obese & $12(15.2)$ & 79 & $24(30.8)$ & 78 & 0.020 \\
\hline Father is obese & $11(16.7)$ & 66 & $16(26.2)$ & 61 & 0.188 \\
\hline Both are obese & $3(3.8)$ & 79 & $5(6.4)$ & 78 & 0.457 \\
\hline $\begin{array}{l}\text { Meal frequency, times per day: } \\
3-4 \\
<3 \\
>4\end{array}$ & $\begin{array}{c}50(63.3) \\
5(6.3) \\
24(30.4) \\
\end{array}$ & 79 & $\begin{array}{c}37(48) \\
7(9.1) \\
33(42.9) \\
\end{array}$ & 77 & 0.159 \\
\hline Meal before bedtime & $34(43)$ & 79 & $44(55.7)$ & 79 & 0.112 \\
\hline Eating at night & $7(8.9)$ & 79 & $8(10.1)$ & 79 & 0.786 \\
\hline Unhealthy eating patterns & $50(63.3)$ & 79 & $66(83.5)$ & 79 & 0.001 \\
\hline $\begin{array}{l}\text { Extracurricular sports } \\
\text { activities }\end{array}$ & $26(32.9)$ & 79 & $23(29.1)$ & 79 & 0.606 \\
\hline $\begin{array}{l}\text { Physical activity level: } \\
1 \\
2 \\
3 \\
4\end{array}$ & $\begin{array}{l}37(46.8) \\
16(20.2) \\
4(5.1) \\
22(27.8) \\
\end{array}$ & 79 & $\begin{aligned} & 35(44.3) \\
& 21(26.6) \\
& 7(8.9) \\
& 16(20.2) \\
&\end{aligned}$ & 79 & 0.476 \\
\hline $\begin{array}{l}\text { Screen time, hours } \\
\leq 2 \\
3-4 \\
>4\end{array}$ & $\begin{array}{l}17(21.5) \\
31(39.2) \\
31(39.2) \\
\end{array}$ & 79 & $\begin{array}{c}19(25.3) \\
26(34.7) \\
30(40)\end{array}$ & 75 & 0.793 \\
\hline
\end{tabular}

Table 2.

Prenatal factors and early life factors for adolescents by weight status

\begin{tabular}{|c|c|c|c|c|c|}
\hline Variable & Normal Weight & & Obesity & $\mathrm{n}$ & $P$-value \\
\hline \multicolumn{6}{|c|}{ Socio-demographics } \\
\hline $\begin{array}{l}\text { Maternal age at the time } \\
\text { of childbirth, yr }\end{array}$ & $25(22 ; 28)$ & 79| & $24(20 ; 28)$ & 78 & 0.132 \\
\hline \begin{tabular}{|l|}
$\begin{array}{l}\text { Maternal age at the time } \\
\text { of childbirth, yr: } \\
<19 \\
19-34 \\
>35\end{array}$ \\
\end{tabular} & $\begin{aligned} 2 & (2.5) \\
71 & (89.9) \\
6 & (7.6)\end{aligned}$ & 79 & $\begin{array}{c}3(3.8) \\
67(85.9) \\
8(10.3)\end{array}$ & 78 & 0.743 \\
\hline $\begin{array}{l}\text { Paternal age at the time } \\
\text { of childbirth, yr }\end{array}$ & $27(25 ; 31)$ & 69 & $26(23 ; 31)$ & 64 & 0.471 \\
\hline \begin{tabular}{|l}
$\begin{array}{l}\text { Paternal age at the time } \\
\text { of childbirth, yr } \\
<19 \\
19-34 \\
>35\end{array}$ \\
\end{tabular} & $\begin{array}{c}1(1.4) \\
58(84.1) \\
10(14.5)\end{array}$ & 69 & $\begin{array}{c}3(4.7) \\
51(79.7) \\
10(15.6)\end{array}$ & 64 & 0.532 \\
\hline \begin{tabular}{|l|} 
Maternal occupation \\
during pregnancy: \\
housewife \\
work in public service \\
manual worker \\
self-employed entrepreneur \\
student
\end{tabular} & $\begin{array}{l}30(38.5) \\
42(53.8) \\
2(2.6) \\
2(2.6) \\
2(2.6) \\
\end{array}$ & 78 & $\begin{array}{l}34(44.2) \\
29(37.7) \\
2(2.6) \\
4(5.2) \\
8(10.4) \\
\end{array}$ & 77 & 0.142 \\
\hline \begin{tabular}{|l|} 
Paternal occupation \\
during pregnancy: \\
unemployed \\
work in public service \\
manual worker \\
self-employed entrepreneur \\
student
\end{tabular} & $\begin{array}{c}20(28.2) \\
25(35.2) \\
21(29.6) \\
4(5.6) \\
1(1.4)\end{array}$ & 71 & $\begin{array}{l}21(37.5) \\
10(17.9) \\
18(32.1) \\
3(5.4) \\
4(7.1)\end{array}$ & 56 & 0.138 \\
\hline
\end{tabular}

\begin{tabular}{lll} 
student & $1(1.4)$ & 4 \\
\hline
\end{tabular}

\begin{tabular}{|c|c|c|c|c|c|}
\hline Anemia in pregnancy & $36(48)$ & 75 & $32(48.5)$ & 66 & 0.954 \\
\hline Risk of preterm labour & $13(17.3)$ & 75 & $6(9.1)$ & 66 & 0.153 \\
\hline \begin{tabular}{|l|} 
Birth order: \\
1 \\
2 \\
3 \\
$>4$ \\
\end{tabular} & $\begin{array}{c}42(53.2) \\
24(30.4) \\
9(11.4) \\
4(5.1) \\
\end{array}$ & 79 & $\begin{array}{c}44(55.7) \\
26(32.9) \\
6(7.6) \\
3(3.9) \\
\end{array}$ & 79 & 0.742 \\
\hline Cesarean delivery & $7(9.3)$ & 75 & $5(7.5)$ & 67 & 0.689 \\
\hline Birth length, $\mathrm{cm}$ & $51(50 ; 52)$ & 79 & $52(51 ; 53)$ & 79 & 0.079 \\
\hline Birth weight, gr & $\begin{array}{c}3110 \\
(3190 ; 3600) \\
\end{array}$ & 79 & $\begin{array}{c}3350 \\
(3100 ; 3600) \\
\end{array}$ & 79 & 0.778 \\
\hline $\begin{array}{l}\text { Birth weight, gr: } \\
<2500 \\
2500-3999 \\
>4000 \\
\end{array}$ & $\begin{array}{c}2(2.5) \\
71(89.9) \\
6(7.6) \\
\end{array}$ & 79 & $\begin{array}{c}2(2.5) \\
74(93.7) \\
3(3.8) \\
\end{array}$ & 79 & 0.588 \\
\hline Apgar scores, $1 \mathrm{~min}$ & $7(7 ; 8)$ & 79 & $7(7 ; 8)$ & 79 & 0.812 \\
\hline Apgar scores, $5 \mathrm{~min}$ & $8(8 ; 8)$ & 79 & $8(8 ; 9)$ & 79 & 0.490 \\
\hline $\begin{array}{l}\text { Breastfeeding duration: } \\
\text { never } \\
<4 \text { month } \\
4-6 \text { month } \\
7-12 \text { month } \\
>12 \text { month } \\
\end{array}$ & $\begin{array}{c}2(2.5) \\
2(2.5) \\
15(19) \\
39(49.4) \\
21(26.6)\end{array}$ & 79 & $\begin{array}{c}0 \\
4(5.1) \\
20(25.3) \\
53(67.1) \\
2(2.5) \\
\end{array}$ & 79 & 0.0003 \\
\hline $\begin{array}{l}\text { Exclusive breastfeeding, } \\
\text { month }\end{array}$ & $4.2(4 ; 5)$ & 79 & $4(4 ; 5)$ & 79 & 0.722 \\
\hline $\begin{array}{l}\text { Additional formula } \\
\text { before } 4 \text { months }\end{array}$ & $9(11.7)$ & 77 & $14(17.7)$ & 79 & 0.288 \\
\hline $\begin{array}{l}\text { Additional cow milk } \\
\text { before } 4 \text { months }\end{array}$ & $5(6.3)$ & 79 & $7(8.9)$ & 79 & 0.548 \\
\hline $\begin{array}{l}\text { Time of solid foods } \\
\text { initiation, months }\end{array}$ & $5(4 ; 5)$ & 79 & $5(4 ; 6)$ & 79 & 0.722 \\
\hline $\begin{array}{l}\text { First solid food: } \\
\text { milk porridge } \\
\text { vegetables } \\
\text { meat soup } \\
\text { other } \\
\end{array}$ & $\begin{array}{c}69(88.5) \\
6(7.7) \\
2(2.6) \\
1(1.3) \\
\end{array}$ & $78 \mid$ & $\begin{array}{c}58(74.4) \\
12(15.4) \\
4(5.1) \\
4(5.1) \\
\end{array}$ & 78 & 0.125 \\
\hline $\begin{array}{l}\text { Weight gain from birth } \\
\text { to } 12 \text { month, gr } \\
\end{array}$ & $\begin{array}{c}7170 \\
(7087 ; 7273) \\
\end{array}$ & 79 & $\begin{array}{c}7396 \\
(7200 ; 7989) \\
\end{array}$ & 79 & .0001 \\
\hline Weight at 1 year, gr & $\begin{array}{c}10520 \\
(10304 ; 10830)\end{array}$ & 1 & $\begin{array}{c}10875 \\
(10518 ; 11230) \\
\end{array}$ & 7 & .00 \\
\hline
\end{tabular}


There were no significant peculiarities identified in the prenatal and perinatal period of adolescents with different weight. But the proportion of adolescents that were breastfed after the first year of life was higher among those with normal weight, while the duration of exclusive breastfeeding was similar in both groups. It should be noted that the adolescents with obesity had significant weight gain during the first year of life, which formed significant intergroup differences in the body weight of infants aged 1 year old.

The odds ratios (ORs) associated with obesity for variables were calculated individually in a univariate model (Table 3). Weight gain during the first year of life, bodyweight at the age of one, maternal BMI, obesity and unhealthy eating patterns were significantly associated with obesity. Breastfeeding for more than 12 months, introduction of porridges as first solid foods, smoking father and mother's occupation in public service during the pregnancy were shown to have a protective role in the univariate models of obesity.

\section{Table 3.}

ORs for obesity in univariate conditional logistic regression model

\begin{tabular}{|c|c|c|c|c|c|c|}
\hline Variable & B & $\begin{array}{l}\text { Std. } \\
\text { error }\end{array}$ & \begin{tabular}{|c|} 
Wald \\
test
\end{tabular} & OR & $95 \% \mathrm{CI}$ & $P$-leve \\
\hline $\begin{array}{l}\text { Mother is } \mathrm{cl} \\
\text { king in the } \mathrm{p}\end{array}$ & -0.58 & 0.34 & 2.95 & 0.56 & $0.29-1.08$ & 0.086 \\
\hline $\begin{array}{l}\text { Family income: } \\
\text { low }\end{array}$ & ref & & & & & \\
\hline average & -0.9 & 0.5 & 3.24 & 0.41 & $0.15-1.08$ & 0.072 \\
\hline above av & -0.24 & 0.67 & 0.13 & 0.79 & 0.21 & 0.719 \\
\hline $\begin{array}{l}\text { Mother working i } \\
\text { lic service during }\end{array}$ & -0.66 & 0.33 & 4.05 & 0.52 & $0.27-0.98$ & 0.044 \\
\hline $\begin{array}{l}\text { Mother stu } \\
\text { during preg }\end{array}$ & 1.48 & 0.81 & 3.37 & 4.41 & $0.90-21.46$ & 0.066 \\
\hline Smoking of a & -0.91 & 0.37 & 6.00 & 0.40 & 0.20 & 0.014 \\
\hline Maternal smoking & 0.56 & 0.38 & 2.19 & 1.75 & $0.83-3.68$ & 0.139 \\
\hline Paternal smoking & -0.98 & 0.34 & 8.4 & 0.38 & $0.19-0.73$ & 0.004 \\
\hline Maternal BMI & 0.15 & 0.04 & 16.81 & 1.16 & $1.08-1.25$ & $<.0001$ \\
\hline Mother is obese & 0.91 & 0.40 & 5.21 & 2.48 & 1.14 & 0.022 \\
\hline $\begin{array}{l}\text { Breastfeeding duration: } \\
<4 \text { month }\end{array}$ & ref & & & & & \\
\hline 4-6 month & -0.40 & 0.93 & 0.19 & 0.67 & $0.11-4.13$ & 0.663 \\
\hline $7-12$ & -0.39 & 0.89 & 0.19 & 0.68 & $0.12-3.90$ & 0.665 \\
\hline$>12$ month & -3.04 & 1.14 & 7.14 & 0.05 & $0.01-0.44$ & 0.008 \\
\hline Milk porridg & -0.97 & 0.44 & 4.90 & 0.38 & $0.16-0.89$ & 0.027 \\
\hline Weight at 1 year & 1.41 & 0.36 & 15.67 & 4.10 & $2.04-8.26$ & 0.0001 \\
\hline $\begin{array}{l}\text { Weight gain from birth to } \\
12 \text { month }\end{array}$ & 1.72 & 0.44 & 15.1 & 5.57 & 2.34 & 0.0001 \\
\hline 3-4 meals per day & -0.62 & 0.33 & 3.64 & 0.54 & $0.28-1.02$ & 0.056 \\
\hline Unhealthy eating patterns & 1.25 & 0.40 & 9.69 & 3.48 & $1.59-7.63$ & 0.002 \\
\hline
\end{tabular}

Variables that were statistically significant, and close to statistically significant differences in OR for obesity, in the univariant analysis were introduced in a multivariate model (Table 4). Since the variables "weight gain during the first year of life" and "body weight at the age of 1", as well as the variables "maternal BMI" and "maternal obesity" are highly correlated, the authors used only those that demonstrated higher significance in the primary models. The analysis showed that the weight gain during the first year of life, maternal BMI and unhealthy eating patterns of adolescents significantly increased the risk of obesity, while breastfeeding for longer than 1 year, passive smoking and mother's occupation in public service were found to be protective factors against obesity. The regression model as a whole explained between $38.5 \%$ (Cox\&Snell R square) and 51.4\% (Nagelkerke R square) of the variance in the obesity status and correctly classified $79.6 \%$ of cases.

Table 4.

Multivariate conditional logistic regression model of risk factors for obesity

\begin{tabular}{|l|c|c|c|c|c|c|}
\hline \multicolumn{1}{|c|}{ Variable } & B & $\begin{array}{c}\text { Std. } \\
\text { error }\end{array}$ & $\begin{array}{c}\text { Wald } \\
\text { test }\end{array}$ & OR & $95 \%$ CI & $P$-level \\
\hline Breastfeeding > 12 month & -3.04 & 1.09 & 7.81 & 0.05 & $0.006-0.40$ & 0.005 \\
\hline Maternal BMI & 0.14 & 0.05 & 9.63 & 1.15 & $1.05-1.26$ & 0.002 \\
\hline Unhealthy eating patterns & 1.12 & 0.49 & 5.36 & 3.08 & $1.19-7.99$ & 0.02 \\
\hline $\begin{array}{l}\text { Mother working in the public } \\
\text { service during pregnancy }\end{array}$ & -0.87 & 0.43 & 4.07 & 0.42 & $0.18-0.97$ & 0.04 \\
\hline $\begin{array}{l}\text { Weight gain from birth } \\
\text { to 12 month }\end{array}$ & 1.58 & 0.50 & 9.98 & 4.87 & $1.82-13.02$ & 0.002 \\
\hline Smoking of any parent & -1.34 & 0.49 & 7.38 & 0.26 & $0.1-0.69$ & 0.007 \\
\hline
\end{tabular}

\section{Discussion}

In the present study, significant factors associated with obesity in adolescents from rural areas were maternal BMI, rapid growth in infancy and current unhealthy patterns. The association of obesity in adolescents with maternal, but not paternal, BMI was a peculiar finding of the present study, because in the majority of other works, obesity was associated with overweight in both parents. ${ }^{(9,10)}$ It can be suggested that the identified association is realized via the primary role of a mother in the formation of family ambience in rural communities, which, in its turn, determines the eating patterns and lifestyle of a child.

Currently, there is some evidence that the postnatal growth during the first 1-2 years of life may be positively associated with subsequent obesity in childhood, adolescence, and adulthood. A recent systematic review of 18 studies showed that the rapid postnatal growth was linearly associated with obesity in children and adolescents of all sizes at birth. ${ }^{(11)}$ These associations are preserved when both the BMI and features of body composition are used as an outcome variable. In the present study, the authors showed significant direct correlation between rapid growth during the first year of life and obesity in adolescents. ${ }^{(12)}$ This correlation did not depend on many sociodemographic, family and behavioral characteristics, which, however, did not exclude its mediation by other confounders (e.g. composition of diet for an infant during the first year of life and further) that were not taken into account in the present study.

The association between obesity and unhealthy eating patterns has been described in many other studies. ${ }^{(13,14)}$ The obtained results prove the importance of measures on the formation of healthy eating habits of children in families and organized social groups. 
When it comes to other risk factors for obesity associated with lifestyle, the results of the present study showed that these factors in adolescents who permanently lived in rural areas differed from the ones in adolescents that lived in urban areas. At least two studies showed that obesity in urban children and adolescents in Russia were associated with low physical activity and a significant increase of time spent in front of a screen. ${ }^{(14,15)}$ In the present study, the level of physical activity in adolescents with obesity was similar to that in adolescents with normal body weight. The percentage of adolescents who spent more than 3 hours per day on screens was rather high in both groups. Probably, the increase of screen time can be considered as a tendency that involves rural communities as well.

These results correspond to the results obtained for other community-based samples of rural and urban children and adolescents. These studies showed that rural children and adolescents were more physically active than urban ones, and the median of their physical activity in the rural sampling was not associated with overweight and obesity, as compared to the urban sampling. ${ }^{(6,16)}$

The factor that showed to have a protective effect against the development of obesity in children was the duration of breastfeeding. The adolescents that were breastfed longer than 12 months had a significantly lower risk of developing obesity as compared to those who were breastfed for a shorter period.

Currently, there are many studies on the association between breastfeeding and obesity in childhood, and more seldom in adolescence. The results of these studies are controversial. A number of studies have shown that there was no association between breastfeeding and obesity in children $^{(17,18)}$ and adolescents. ${ }^{(19)}$ Other studies, as well as the present study, show that there was a dose-dependent influence of breastfeeding on body weight during life. Portela et al., ${ }^{(20)}$ as well as the present study, showed that the children who were breastfed for more than 12 months significantly decreased the risk of obesity as compared to those who were breastfed for a shorter period. Other two studies, ${ }^{(21,22)}$ as well as the present study, showed that the protective effect of longer breastfeeding remains until adolescence.

The inconsistency in the results obtained in different studies can be explained by the peculiarities of the study design, different power, and the influence of socioeconomic, behavioral and other confounders that were not included in all the studies. Jwa et al. ${ }^{(23)}$ showed that the relationship between breastfeeding and obesity became clear with growth, suggesting that breastfeeding has a latent protective effect against childhood obesity. Their results suggest that the studies investigating the effect of breastfeeding in early childhood might be unable to show a significantly slower increase of BMI with age or a protective effect against overweight and obesity because the data were collected too early. Probably, this latent effect of breastfeeding can be associated with the activity of bioactive factors (leptin, adiponectin, insulin, ghrelin, resistin, obestatin, peptide YY, glucagon-like peptide 1) contained in breast milk that can exert a long-term effect on the metabolism and the regulation of appetite in the future, determining the future patterns of body weight. ${ }^{(24)}$
It should be highlighted that smoking by any of the parents had a negative correlation with obesity in adolescents. This contradicts the results of the previous studies on this aspect of obesity, ${ }^{(25)}$ and the results of the studies that focused on the biological effects of passive smoking, and showed that it was independently associated with the degree of inflammation, oxidative stress and endocrine disorders. ${ }^{(26,27)}$ It should be noted that the authors did not find any significant association between obesity in adolescents and current smoking of the mothers. The negative correlation was associated only with fathers' smoking. The authors have no convincing explanation but speculate that these unusual results can be observed for the following reasons: First, the authors did not consider the fact that adolescents' passive smoking could come from nonpaternal sources. Second, due to a great amount of the missed data, the authors could not take into account the fact of smoking by adolescents themselves. Thirdly, it was unknown if fathers smoked outside or inside the house. Fourth, we did not assess the composition of the diet of adolescents. The last factor can be significant because it was shown that dietary fibers and omega-3-polyunsaturated fatty acids can weaken the association between passive smoking and obesity in children. ${ }^{(28)}$ Finally, the information on parents' smoking was obtained from their self-reports, and we did not check for biological markers, like cotinine, that could have characterized quantitatively the level of impact. All the abovementioned facts indicate that the obtained results should be interpreted with caution.

\section{Study limitations}

It was the first comprehensive study on obesity conducted within the rural community-based sample of adolescents in Russia. However, this study has some limitations. First, this is a cross-sectional analysis. Therefore, assumptions about causality cannot be made. Second, the authors did not use specialized questionnaires and special devices to evaluate routine physical activity of adolescents. Instead, the authors used the participants' self-reports. Third, because of a great number of missed answers, the authors could not present the complete information on eating patterns (e.g. regularity of breakfast meals), or on the details of passive smoking.

We conclude that maternal BMI, rapid growth in infancy and unhealthy eating patterns are associated with increased risk of obesity in adolescents in rural areas of Buryatia, while long-term breastfeeding is a protective factor against obesity. The obtained results provide evidence that the first year of a child's life is a unique "period of possibilities" for the prevention of diseases and confirm the importance of family as a complex factor that affects the development of obesity in childhood and the necessity to implement family-oriented disease prevention programs.

\section{Competing Interests}

The authors declare that they have no competing interests.

\section{References}

1. Styne DM, Arslanian SA, Connor EL, Farooqi IS, Murad $\mathrm{MH}$, Silverstein JH, et al. Pediatric Obesity - Assessment, 
Treatment, and Prevention: an Endocrine Society Clinical Practice guideline. J Clin Endocrinol Metab. 2017;102(3):709757. doi: 10.1210/jc.2016-2573.

2. Daniels SR. Complications of obesity in children and adolescents. Int J Obes (Lond). 2009; 33 Suppl 1: S60-65. doi: 10.1038/ijo.2009.20.

3. Tutelyan VA, Baturin AK, Kon IYa, Martinchik AN, Uglitzkih AK, Korosteleva MM, et al. [Prevalence of overweight and obesity in child population of Russia: multicenter study]. Journal "Pediatria" named after G.N. Speransky. 2014;93(5):28-31. doi: 10.24110/0031-403X2014-93-5-28-31. [Article in Russian].

4. Soboleva NP, Rudnev SG, Nikolaev DV, Eryukova TA, Kolesnikov VA, Melnitchenko OA, et al. [The bio-impedance screening of population in health centers: prevalence of surplus body mass and obesity]. Ross Med Zh. 2014;(4):4-13. [Article in Russian].

5. Ng M, Fleming T, Robinson M, Thomson B, Graetz N, Margono C, et al. Global, regional, and national prevalence of overweight and obesity in children and adults during 19802013: a systematic analysis for the Global Burden of Disease Study 2013. Lancet. 2014;384(9945):766-781. doi:10.1016/ S0140-6736(14)60460-8.

6. Gökler ME, Bugrul N, Metintas S, Kalyoncu C. Adolescent obesity and associated cardiovascular risk factors of rural and urban life (Eskisehir, Turkey). Cent Eur J Public Health. 2015;23(1):20-5.

7. Mameli C, Mazzantini S, Zuccotti GV. Nutrition in the First 1000 Days: The Origin of Childhood Obesity. Int J Environ Res Public Health. 2016;13(9).pii:E838 doi:10.3390/ijerph13090838

8. Pisareva LF, Lyakhova NP, Odintsova IN, Perinov DA, Chemitdorzhieva TN, Shukhoeva YA. [Demographic characteristics of the Republic of Buryatia]. Bulletin of Siberian Medicine. 2015;14(3):23-29. [Article in Russian\}.

9. Bahreynian M, Qorbani M, Khaniabadi BM, Motlagh ME, Safari O, Asayesh H, Kelishadi R. Association between obesity and parental weight status in children and adolescents. J Clin Res Pediatr Endocrinol. 2017;9(2):111-117. doi:10.4274/jcrpe.3790.

10. Donkor HM, Grundt JH, Júlíusson PB, Eide GE, Hurum J, Bjerknes R, Markestad T. Social and somatic determinants of underweight, overweight and obesity at 5 years of age: a Norwegian regional cohort study. BMJ Open. 2017; 7(8):e014548. doi:10.1136/ bmjopen-2016-014548.

11. Matthews EK, Wei J, Cunningham SA. Relationship between prenatal growth, postnatal growth and childhood obesity: a review. Eur J Clin Nutr. 2017;71(8):919-930. doi: 10.1038/ejcn.2016.258.

12. Eriksson M, Tynelius P, Rasmussen F. Associations of birthweight and infant growth with body composition at age 15-the COMPASS study. Paediatr Perinat Epidemiol. 2008; 22(4):379-88. doi: 10.1111/j.1365-3016.2008.00944.x.

13. Lazzeri G, Giacchi MV, Spinelli A, Pammolli A, Dalmasso $\mathrm{P}$, Nardone $\mathrm{P}$, et al. Overweight among students aged $11-15$ years and its relationship with breakfast, area of residence and parents' education: results from the Italian HBSC 2010 cross-sectional study. Nutr J. 2014;13:69. doi: 10.1186/1475-2891-13-69.

14. Vitebskaya AV, Pisareva EA, Popovich AV. [Lifestyle in children and adolescents with obesity: results of the survey of patients and their parents]. Obesity and Metabolism. 2016;
3(2):33-40. doi: 10.14341/omet2016233-40. [Article in Russian]. 15. Krasnoperova OI, Smirnova EN, Chistousova GV, Baturin VI, Toropova EA. [Determinants of obesity in children and adolescents]. Obesity and Metabolism. 2013;1(34):18-21. [Article in Russian].

16. Vitáriušová E, Babinská $K$, Košt'álová L, Rosinský J, Hlavatá A, Pribilincová Z, et al. Food intake, leisure time activities and the prevalence of obesity in schoolchildren in Slovakia. Cent Eur J Public Health. 2010;18(4):192-197

17. Lausten-Thomsen U, Bille DS, Nässlund I, Folskov L, Larsen T, Holm JC. Neonatal anthropometrics and correlation to childhood obesity - data from the Danish Children's Obesity Clinic. Eur J Pediatr. 2013;172(6):747-51. doi: 10.1007/s00431-013-1949-z.

18. Skledar MT, Milosevic M. Breastfeeding and time of complementary food introduction as predictors of obesity in children. Cent Eur J Public Health. 2015;23(1):26-31

19. Orlandi SP, González-Chica DA, Buffarini R, Gonzalez MC, Menezes AMB, Barros FC et al. Breastfeeding and complementary feeding associated with body composition in 18-19 years old adolescents in the 1993 Pelotas Birth Cohort. BMC Nutr. 2017;3:84. doi: 10.1186/s40795-017-0201-z

20. Portela DS, Vieira TO, Matos SM, de Oliveira NF, Vieira GO. Maternal obesity, environmental factors, cesarean delivery and breastfeeding as determinants of overweight and obesity in children: results from a cohort. BMC Pregnancy Childbirth. 2015;15(1):94. doi: 10.1186/s12884-015-0518-z. 21. Byrne ML, Schwartz OS, Simmons JG, Sheeber L, Whittle S, Allen NB. Duration of breastfeeding and subsequent adolescent obesity: effects of maternal behavior and socioeconomic status. J Adolesc Health 2018;62(4):471479. doi: 10.1016/j.jadohealth.2017.10.019.

22. Gillman MW, Rifas-Shiman SL, Camargo CA Jr, Berkey CS, Frazier AL, Rockett HR, et al. Risk of overweight among adolescents who were breastfed as infants. JAMA 2001; 285(19):2461-7.

23. Jwa SC, Fujiwara T, Kondo N. Latent protective effects of breastfeeding on late childhood overweight and obesity: a nationwide prospective study. Obesity (Silver Spring). 2014;22(6):1527-37. doi: 10.1002/oby.20735.

24. Poulton R, Williams S. Breastfeeding and risk of overweight. JAMA 2001; 286(12):1449-50.

25. Kwok MK, Schooling CM, Lam TH, Leung GM. Paternal smoking and childhood overweight: evidence from the Hong Kong “Children of 1997'. Pediatrics. 2010;126(1):e46-56. doi: 10.1542/peds.2009-2642.

26. Barnoya J, Glantz SA. Cardiovascular effects of secondhand smoke: nearly as large as smoking. Circulation. 2005;111(20):2684-98.

27. Darenskaya MA, Gavrilova OA, Rychkova LV, Kravtsova OV, Grebenkina LA, Osipova EV, et al. The assessment of oxidative stress intensity in adolescents with obesity by the integral index. International Journal of Biomedicine. 2018; 8(1):37-41. doi: 10.21103/Article8(1)_OA5

28. Moore BF, Clark ML, Bachand A, Reynolds SJ, Nelson TL, Peel JL. Interactions between diet and exposure to secondhand smoke on the prevalence of childhood obesity: results from NHANES, 2007-2010. Environ Health Perspect. 2016;124(8):1316-22. doi: 10.1289/ehp.1510138. 